\title{
DAYA CERNA PROTEIN KASAR, LEMAK KASAR DAN SERAT KASAR RANSUM KOMPLIT MENGANDUNG BAHAN UTAMA TUMPI JAGUNG FERMENTASI PADA TERNAK KAMBING KACANG
}

(Digestibility of crude protein, crude fat and crude fiber complete ration contains the main ingredients of corn stalk in Capra aegagrus)

\author{
A. Antisa ${ }^{1)^{*}}$, A. Natsir ${ }^{2)}$, S. Syahrir ${ }^{2)}$ \\ ${ }^{1)}$ Mahasiswa Program Strata Satu Fakultas Peternakan, Universitas Hasanuddin. \\ ${ }^{2)}$ Fakultas Peternakan, Universitas Hasanuddin. \\ *Email: antisaayuu@gmail.com
}

\begin{abstract}
Digestibility of feed material is part of a substance that can be digested by the body and assumed to be absorbed by the body of livestock so that it is not excreted in feces. The amount and chemical composition of the fiber of a feed ingredient is very influential on its digestibility. The purpose of this study was to evaluate the protein digestibility, fat digestibility, and digestibility of complete feed fiber containing fermented cornmeal in goats. This study used ten randomly distributed kacang goats into two treatment groups (5 head / group). Group (F) was given complete feed containing fermented blunt and in group (TF) was given complete feed containing blended fermentation. The results showed that the two treatments had no significant effect $(\mathrm{P}>0.05)$ on protein digestibility, fat digestibility and crude fiber digestibility. Conclusion The provision of complete fermented corn ration and fermented corn ration without fermentation showed no difference in the digestibility of protein, fat and goat fiber caused by almost the same nutrient content in each treatment.
\end{abstract}

Keywords: Corn Stalk, Fermentation, Digestibility, goat

\begin{abstract}
ABSTRAK
Daya cernaan bahan pakan adalah bagian zat yang dapat dicerna oleh tubuh dan diasumsikan diserap oleh tubuh ternak sehingga tidak diekskresikan dalam feses. Jumlah maupun komposisi kimia serat suatu bahan pakan sangat berpengaruh terhadap kecernaannya. Tujuan penelitian ini untuk mengevaluasi daya cerna protein, daya cerna lemak, dan daya cerna serat pakan komplit mengandung tumpi jagung fermentasi pada ternak kambing kacang. Penelitian ini menggunakan Sepuluh ekor ternak kambing kacang secara random dibagi kedalam dua kelompok perlakuan (5 ekor/kelompok). Kelompok (F) diberi pakan komplit mengandung tumpi fermentasi dan pada kelompok (TF) diberi pakan komplit mengandung tumpi tanpa fermentasi. Hasil penelitian menunjukkan bahwa kedua perlakuan tidak berpengaruh nyata
\end{abstract}


$(\mathrm{P}>0,05)$ terhadap daya cerna protein, daya cerna lemak dan daya cerna serat kasar pakan. Kesimpulan Pemberian ransum komplit tumpi jagung fermentasi dan ransum komplit tumpi jagung tanpa fermentasi kecernaan protein dari kedua perlakuan cukup tinggi yaitu berada di angka diatas $70 \%$ begitupula dengan kecernaan lemak juga cukup tinggi yaitu rataan diatas $80 \%$ dan kecernaan serat rataan diatas $50 \%$.

Kata kunci: Tumpi Jagung, Fermentasi, Daya Cerna, dan Kambing Kacang

\section{PENDAHULUAN}

Sulawesi Selatan merupakan daerah yang memiliki lahan pertanian luas dan variatif sehingga potensi limbah pertanian untuk dapat digunakan sebagai pakan terutama ternak ruminansia cukup besar.Akan tetapi pemanfaatan limbah pertanian untuk pakan belum dilakukan secara optimal, umumnya limbah pertanian hanya dibakar begitu saja dan sebagian kecil digunakan sebagai pupuk organik.Pemanfaatan limbah sebagai bahan pakan tentu menjadi solusi untuk mengatasi kurangnya persediaan hijauan pada musim tertentu dan dapat mengurangi pencemaran lingkungan oleh limbah pertanian.

Faktor pembatas dari limbah pertanian sebagai pakan adalah protein yang rendah dan sudah terjadi lignifikasi lanjut sehingga selulosa terikat oleh lignin.Lignifikasi meningkat sejalan dengan meningkatnya umur tanaman. Selulosa dan hemiselulosa merupakan karbohidrat struktural penyusun utama dinding sel tanaman, dan sering berikatan dengan lignin dalam bentuk kristal lignoselulı Lignoselulosa merupakan komponen utama tanaman dan terdapat pada dinding sel. Lignoselulosa terdiri dari selulosa, hemiselulosa dan lignin.Selulosa merupakan penyusun dinding sel tanaman yang sukar didegradasi.

Solusi dari tingginya kandungan serat kasar dari limbah tanaman jagung yaitu dengan melakukan berbagai macam cara pengolahan seperti perlakuan fisik, kimia, dan biologi, sehingga dapat dimanfaatkan sebagai pakan yang potensial .Pemanfaatan limbah tanaman jagung yang cukup melimpah perlu di optimalkan dengan teknologi fermentasi.Fermentasi dilakukan dengan menggunakan bakteri rumen kerbau yang dapat memecah setat kasar.Pembuatan pakan fermentasi bakteri rumen kerbau sebagai starter yang digunakan syang akan membatu menstimulir peningkatan gizi 
pakan fermentasi dan mempertahankan kualitas pakan, namun belum diketahui pengaruhnya terhadap kandungan nutrisi.Oleh karena itu perlu di lakukan penelitian mengenai kecernaan protein kasar, serat kasar dan lemak kasar pakan komplit tumpi jangung terfermentasi.

\section{METODE PENELITIAN}

\section{Waktu dan Tempat Penelitian}

Penelitian ini telah dilaksanakan pada bulan November sampai Desember 2019. yang terdiri atas dua tahap. Tahap pertama yaitu pembuatan pakan fermantasi tumpi jangung menggunakan bakteri rumen kerbau di Laboratorium Pemuliaan Unit Kandang Kambing Fakultas Peternakan,Universitas Hasanuddin tahap kedua analisis kandungan protein kasar, dan lemak kasar,dan serat kasar dilakukan di Laboratorium Kimia Makanan Ternak, Fakultas Peternakan, Universitas Hasanuddin, Makassar, Sulawesi Selatan.

\section{Materi Penelitian}

Peralatan yang digunakan dalam penelitian ini adalah disk mill, silo (gentong kedap udara), blender, sekop, ember, karung penampung feses dan timbangan.

Bahan yang digunakan dalam penelitian ini adalah kambing, tumpi jagung halus, biostarter bakteri rumen kerbau, dedak, urea, molasses, garam, air, mineral, bungkil kelapa, dan selotip/lakban.

\section{Metode Pelaksanaan a.Rancangan penelitian}

Penelitian ini menggunakan uji $\mathrm{T}$ (Independent Sample T-Test) dengan menggunakan aplikasi SPSS dan Excel. Kecernaan nutrisi pakan komplit menggunakan tongkol jagung terfermentasi tehadap kambing kacang dengan dua perlakuan dan lima ulangan. Adapun susunan perlakuan yang digunakan sebagai berikut:

$\mu 1=$ Kecernaan pakan komplit mengandung tongkol jagung terfermentasi dan 
$\mu 2=$ Kecernaan pakan komplit mengandung tongkol jagung tanpa fermentasi

\section{b. Prosedur Penelitian}

\section{Pembuatan Tumpi Fermentasi}

Adapun prosedur pembuatan pakan fermentasi tumpi jagung dengan menggunakan biostarter bakteri rumen kerbausebagai berikut:

a. Menimbang semua bahan pakantumpi jagung halus $77.5 \%$, biostarter (bakteri rumen kerbau) $3.5 \%$, molasses $1.5 \%$, urea $1.5 \%$, dan air $15 \%$.

b. Mencampur semua bahan secara rata hingga homogen.

c. Masukkan pakan yang sudah homogen kedalam silo/gentong kemudian menutup rapat dan mengunci tutup silo/gentong kemunian melakban penutup silo/gentong untuk memastikan tidak akan udara yang masuk.

d. Menyimpan pakan yang telah dimasukkan kedalam silo/gentong selama 3 minggu ditempat yang aman dan terhindar dari sinar matahari langsung.

e. Membuka silo pada minggu ke 3 dan mengambil 100 gram setiap sampel untuk dikeringkan di oven dengan suhu $60^{\circ} \mathrm{C}$ selama 3 hari.

f. Analisis laboratorium proksimat pakan

g. Tumpi jagung fermentasi siap digunakan

\section{Pakan Komplit}

Adapun prosedur pembuatan pakan komplit mengandung tongkol jagung terfermentasi dan tanpa fermentasi dapat dilihat pada gambar berikut:

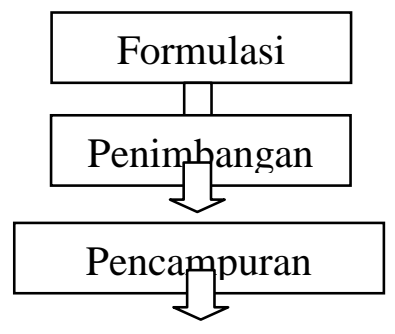

Pakan Silase Tumpi Fermentasi Siap Digunakan

Gambar 2. Prosedur pembuatan pakan komplit mengandung tongkol jagung fermentasi dan tanpa fermentasi

\section{Komposisi Bahan Pakan dalam Ransum Komplit sebagai Berikut}


Komposisi bahan pakan, komposisi ransum percobaan dan kandungan nutrisi pakan dpat dilihat pada tabel 3 dan tabel 4.

Tabel 3. Komposisi Bahan Pakan

\begin{tabular}{lcccc}
\hline \multicolumn{1}{c}{ Bahan } & Bahan Kering & Protein & Serat & Lemak \\
\hline Tumpi Fermentasi & $83.6^{*}$ & $15^{*}$ & 25.38 & 1.8 \\
Tumpi & $80.6^{*}$ & $8^{*}$ & 25.38 & 1.8 \\
Dedak & 89.6 & 11 & 11.4 & 13 \\
Tepung Rese & 90.4 & 43 & 17.59 & 6.62 \\
Bungkil Kelapa & 87.9 & 18.6 & 15 & 2 \\
Mineral & - & - & - & - \\
Garam & - & - & - & - \\
Urea & - & 287.5 & - & - \\
\hline Sumber: Hartadi & & & - & \\
\hline
\end{tabular}

Sumber: Hartadi dkk. 2005 ( * Hasil analisis laboratorium)

Tabel 4. Susunan Formulasi Ransum Pakan Fermentasi Tongkol Jagung

\begin{tabular}{lcc}
\hline \multicolumn{1}{c}{ Bahan } & Tumpi Terfermentasi & Tumpi Tanpa Fermentasi \\
\hline Tumpi & 60 & 60 \\
Dedak & 25 & 23.5 \\
Tepung Rese & 5 & 5 \\
Bungkil Kelapa & 7 & 7 \\
Mineral & 2 & 2 \\
Garam & 1 & 1 \\
Urea & & 1.5 \\
\hline \multicolumn{1}{c}{ Jumlah } & 100 & 100 \\
\hline Kandungan Nutrisi & & \\
\hline Bahan Kering & 80.13 & 81.13 \\
Protein Kasar & 15.2 & 15.26 \\
Lemak Kasar & 4.6 & 4.6 \\
Serat Kasar & 18.57 & 20 \\
\hline *Hasil Perhitungan & &
\end{tabular}

*Hasil Perhitungan 
Penelitian dilakukan selama 30 hari, 25 hari untuk periode pembiasaan dan koleksi sampel .Ternak kambing ditempatkan pada kandang individu berukuran 1,5m x 0,6 m, dengan ketinggian dari lantai kurang lebih 0,5 m. kandang individu tersebut dilengkapi dengan tempat pakan dan tempat minum yang terpisah demikian pula kandang tersebut didesain sedemikian rupa sehingga feses dan urine dapat dipisahkan. Setelah itu dilakukan pembiasaan pemberian pakan hingga pakan yang dikomsumsi stabil.

Setalah komsumsi pakan stabil selama seminggu dilakukan pemberian pakan komplit secara addlibitum, pemberian pakan secara addlibitum ini dilakukan dengan cara membagi pakan dalam beberapa bagian yang masing-masing bagian berisi 100gr pakan komplit, kemudian diberikan kepada ternak masing-masing satu bagian, kemudian menunggu hingga habis dan perlakuan tersebut hingga ternak betul-betul kenyang. Untuk menentukan kecernaan pakan masing-masing ternak $80 \%$ dari komsumsi addlibitm.Ransum komplit yang digunakan disusun sedemikian rupa sehingga tumpi jagung berbeda.Air minum untuk ternak tersedia setiap saat.

Sebelum melakukan sampling dilakukan pembiasaan selama 25 hari dan pengambilan sampel untuk penetapan kecernaan pakan dilakukan 5 hari terakhir dari periode percobaan.Jumlah feses yang terkumpul selama 5 hari koleksi data ditimbang untuk diketahui beratnya lalu disampel (10\%). Sampel feses yang terkumpul selama 5 hari selanjutnya dicampur secara homogen lalu dilakukan sub sampling, sampling sebanyak $10 \%$ dari total sampel untuk selanjutnya dianalisis kandungan protein kasar, lemak kasar, serat kasar. Pada periode ini, juga dilakukan sampling terhadap pakan komplit yang diberikan pada ternak.Sampel selama periode koleksi dikumpulkan dan disubsampel untuk analisis kandungan protein kasar, lemak kasar, dan serat kasar.

Sampel pakan dan feses yang diperoleh pada periode sampling dioven pada suhu $65^{\circ} \mathrm{c}$ salama 48 jam, selanjutnya sampel pakan dan feses digiling hingga halus untuk selanjutnya dilakukan analisa kandungan protein kasar, lemak kasar,dan serat kasar. Penentuan kandungan protein kasar, lemak kasar, dan serat kasar sampel pakan dan feses ditetapkan mengikuti prosedur dari AOAC (2000) 
Parameter Penelitian

Kecernaan Protein Kasar

Kecernaan protein kasar pakan komplit yang mengandung tongkol jagung terfermentasi terhadap kambing kacang diukur dengan cara menghitung selisih protein ransum yang dikonsumsi dengan protein yang keluar bersama feses, kemudian dibagi protein ransum yang dikonsumsi, lalu dikali 100\% dihutung berdasarkan rumus secara matematis sebagai berikut:

Kecernaan Protein Kasar $=\frac{P K \text { pakayang dikomsumsi }-P K \text { Feses }}{\text { PK pakayang dikomsumsi }} \times 100 \%$

\section{Kecernaan Serat Kasar}

Kecernaan serat kasar pakan komplit yang mengandung tongkol jagung terfermentasi terhadap kambing kacang diukur dengan cara menghitung selisih protein ransum yang dikonsumsi dengan protein yang keluar bersama feses, kemudian dibagi protein ransum yang dikonsumsi, lalu dikali 100\% dihutung berdasarkan rumus secara matematis sebagai berikut

Kecernaan Serat Kasar $=\frac{S K \text { pakan yang dikomsumsi }(g)-S K \text { Feses }(g)}{\text { SK pakayang dikomsumsi }(g)} \times 100 \%$

\section{Kecernaan Lemak Kasar}

Kecernaan lemak kasar pakan komplit yang mengandung tongkol jagung terfermentasi terhadap kambing kacang diukur dengan cara menghitung selisih protein ransum yang dikonsumsi dengan protein yang keluar bersama feses, kemudian dibagi protein ransum yang dikonsumsi, lalu dikali $100 \%$ dihutung berdasarkan rumus secara matematis sebagai berikut

KecernaanLemak Kasar $=\frac{L K \text { pakan yang dikomsumsi }(g)-L K \text { Feses }(g)}{\text { LK pakayang dikomsumsi }(g)} \times 100 \%$

\section{c. Analisis Data}

Data yang diperoleh dianalisis berdasarkan uji $\mathrm{T}$ untuk dua rata-rata berdasarkan model matematik sebagai berikut: 


\section{Statistik Uji}

$$
t_{h}=\frac{(\bar{X} 1-\bar{X} 2)-\delta_{o}}{S(\bar{X} 1-\bar{X} 2)}
$$

Jika diasumsikan ragam kedua populasi sama besar atau $\sigma^{2}{ }_{1}=\sigma_{2}^{2}$

$S(\bar{X} 1-\bar{X} 2)=S_{g} \sqrt{\frac{1}{n_{1}}+} \frac{1}{n_{2}} \operatorname{dengan} S_{g}=\sqrt{\frac{\left(n_{1}-1\right) \mathrm{s}_{1}^{2}+\left(n_{2}-1\right) \mathrm{s}_{2}^{2}}{\mathrm{n}_{1}+n_{2}-2}}$

Jika diasumsikan ragam kedua populasi tidak sama besar atau $\sigma^{2}{ }_{1} \neq \sigma_{2}^{2}$

$$
S(\bar{X} 1-\bar{X} 2)=\sqrt{\frac{s_{1}^{2}}{n_{1}}+\frac{s_{2}^{2}}{n_{2}}}
$$

Keterangan:

$t \quad=$ Parameter yang diukur

$\mathrm{Sg} \quad=$ Simpangan baku gabungan

$\mathrm{x}_{1} \quad=$ Rata-rata parameter pada kecernaan nutrisi kambing yang diberi pakan komplit tumpi jagung terfermentasi

$\mathrm{x}_{2}=$ Rata-rata parameter pada kecernaan nutrisi kambing yang diberi pakan komplit tumpi jagung

$\mathrm{S}_{1} \quad=$ Simpangan baku perlakuan kecernaan nutrisi kambing yang diberi pakan komplit tumpi jagung terfermentasi

$\mathrm{S}_{2} \quad=$ Simpangan baku perlakuan kecernaan nutrisi kambing yang diberi pakan komplit tumpi jagung

$n_{1} \quad=$ Jumlah kambing betinayang diberi pakan komplit terfermentasi

$n_{2} \quad=$ Jumlah kambing betinayang diberi pakan komplit tanpa fermentasi

\section{HASIL DAN PEMBAHASAN}

Rataan nilai daya cerna protein kasar, lemak kasar, dan serat kasar pakan komplit mengandung tumpi fermentasi maupun pakan komplit mengandung tumpi jagung tanpa fermentasi pada ternak kambing dapat dilihat pada Tabel 4. 
A.Antisa, A. Natsir, S. Syahrir / Bulletin Makanan Ternak, 2020-02-11: 1-13

Tabel 4. Rataan Kecernaan Protein, Lemak dan Serat pada Ternak Kambing Kacang Betina berdasarkan perlakuan.

\begin{tabular}{lcc}
\hline \multirow{2}{*}{ Parameter } & \multicolumn{2}{c}{ Perlakuan } \\
\cline { 2 - 3 } & Fermentasi & Tanpa Fermentasi \\
\hline Protein (\%) & 70.34 & 72.71 \\
Lemak (\%) & 81.11 & 83.75 \\
Serat (\%) & 53.42 & 56.44 \\
\hline
\end{tabular}

\section{Kecernaan Protein}

Hasil sidik ragam menunjukkan bahwa pemberian ransum komplit fermentasi dan tanpa fermentasi terhadap kambing kacang betina tidak berpengaruh nyata $(\mathrm{P}>0,05)$ terhadap kecernaan protein. Artinya kedua perlakuan yang diberikan pada kambing sama pengaruhnya terhadap daya cerna protein pada kambing kacang. Morand-Fehr (1981) menyatakan bahwa kisaran koefisien kecernaan protein kasar pada kambing yaitu 23-75\%.Hasil rata-rata kecernaan protein kasar pada penelitian ini ransum fermentasi berkisar antara $70.34 \%$. Rataan kecernaan protein kasar yang tertinggi pada tanpa fermentasi yaitu $72,71 \%$. Hasil tersebut lebih tinggi dari penelitian Aregheore (2000) yang menyatakan bahwa kecernaan protein kasar pada kambing yang diberi pakan tongkol jagung sebesar 70,1\% dan jauh lebih tinggi dibandingkan dengan penelitian Rahman et al. (2013) yang menyatakan bahwa kecernaan protein kasar pada kambing yang diberi pakan bungkil inti sawit sebesar $52,1 \%$.

Semakin tinggi koefisien kecernaan protein kasar berbanding lurus dengan peningkatan bobot badan ternak.Kecernaan dapat dipengaruhi oleh beberapa faktor seperti komposisi bahan pakan, perbandingan komposisi antara bahan pakan satu dengan bahan pakan lainnya, perlakuan pakan, suplementasi enzim dalam pakan, ternak dan taraf pemberian pakan (McDonald et al., 2002). Gultom et al. (2016) menambahkan bahwa pemberian ransum dengan perlakuan fisik (chooper), biologi (chooper dan Aspergillus niger) dan kimia (chooper dan urea) mempengaruhi kecernaan protein kasar. Paramita et al. (2008) menyatakan secara in vivo kualitas bahan pakan yang diberikan dilihat melalui konsumsi dan besarnya nilai kecernaan 
yakni indikator banyaknya nutrisi yang dapat dimanfaatkan sebagai kebutuhan hidup pokok serta pertumbuhan.

Tillman dkk (2005) menyatakan bahwa salah satu faktor yang mempengaruhi kecernaan protein kasar adalah kandungan protein dalam ransum yang dikonsumsi ternak.Ransum dengan kandungan protein rendah, umumnya mempunyai kecernaan yang rendah pula dan sebaliknya.Tinggi rendahnya kecernaan protein dipengaruhi oleh kandungan protein bahan ransum dan banyaknya protein yang masuk dalam saluran pencernaan.

\section{Kecernaan Lemak}

Hasil sidik ragam menunjukkan bahwa pemberian ransum komplit fermentasi dan tanpa fermentasi terhadap kambing kacang betina tidak berpengaruh nyata $(\mathrm{P}>0,05)$ terhadap kecernaan lemak. Hal ini dikarenakan Hal ini disebabkan daya cerna lemak kasar tiap ternak terhadap pakan berbeda dan dipengaruhi banyak hal, termasuk kualitas pakan.Hal ini sesuai dengan pernyataan Sandri (2009) yangmenyatakan bahwa kemampuan kecernaan suatu pakan tergantung pada kualitas zat makanan yang terdapat di dalam pakan sehingga berpengaruh terhadap pertumbuhan mikroorganisme.Komposisi kimia pakan akan mempengaruhi daya cerna pakan, disebabkan daya cerna suatu pakan tergantung pada keserasian dari zatzat makanan yang terkandung di dalamnya. Pengolahan secara fisik, kimia dan kombinasi yang menyebabkan meningkatnya daya cerna pakan. Hal ini sesuai dengan pernyataan Tillman, et al., (1981) yang menyatakan bahwa daya cerna tidak hanya

dipengaruhi oleh komposisi suatu pakan tetapi juga dipengaruhi komposisi suatu makanan lain yang ikut dikonsumsi bersama pakan tersebut.

Hal ini disebut "efek asosiasi".Cara yang lebih baik adalah dengan penambahan secara bertingkatdari bahan makanan yang diteliti untuk menentukan pengaruh pakan basal terhadap daya cerna bahan yang sedang diteliti.Serat kasar mempunyai pengaruh terbesar terhadap daya cerna. Selulosa dan hemiselulosa yang sukar dicerna terutama bila mengandung lignin dan hal ini seiring dengan pernyataan Ranjhan dan Pathak (1979), disitasi Siregar (2009) yang menyatakan bahwa salah 
satu faktor yang harus dipenuhi dalam bahan pakan adalah tingginya daya cerna bahan pakan tersebut, dalam arti bahwa pakan itu harus mengandung zat pakan yang dapat diserap dalam saluran pencernaan dan zat pakan yang terkandung tidak seluruhnya tersedia untuk tubuh ternak, sebagian besar dikeluarkan lagi melalui feses karena tidak tercerna.

\section{Kecernaan Serat}

Hasil sidik ragam menunjukkan bahwa pemberian ransum komplit fermentasi dan tanpa fermentasi terhadap kambing kacang betina tidak berpengaruh nyata $(\mathrm{P}>0,05)$ terhadap kecernaan serat karena jenis dan kualitas bahan pakan sumber serat yang diberikan pada keduat perlakuan sama sehingga degradasi serat dalam rumen hampir sama. Hal ini sesuai dengan pendapat McDonald et al. (1995) menyatakan bahwa fraksi serat pakan sangat menentukan kecernaan baik dalam jumlah maupun komposisi kimia serat itu sendiri. Diperkuat oleh pendapat Tillman dkk., (2005) menyatakan bahwa kecernaan serat kasar tergantung pada kandungan serat kasar dalam ransum dan jumlah serat kasar yang dikonsumsi. Kadar serat kasar terlalu tinggi dapat mengganggu pencernaan zat lain.

Selain kandungan dan jumlah serat kasar dalam ransum faktor lain yang mempengaruhi daya cerna serat kasar adalah aktivitas bakteri selulolitik di dalam rumen. Maynard et al. (2005) menyatakan daya cerna serat kasar dipengaruhi oleh beberapa faktor antara lain kadar serat dalam pakan, komposisi penyusun serat kasar dan aktivitas mikroorganisme.

\section{KESIMPULAN}

Pemberian ransum komplit tumpi jagung fermentasi dan ransum komplit tumpi jagung tanpa fermentasi kecernaan protein dari kedua perlakuan cukup tinggi yaitu berada di angka diatas $70 \%$ begitupula dengan kecernaan lemak juga cukup tinggi yaitu rataan diatas $80 \%$ dan kecernaan serat rataan diatas $50 \%$. 


\section{DAFTAR PUSTAKA}

AOAC. 2000.Association of Official Analytical Chemists, Official Methods of Analysis.Washington.DC.,USA

Aregheore, J., L. Krizova, M. Richter, V. Carry, and J. Riha.2000-.Effect of rumenprotected methionine, lysine or both on milk production and plasma amino acid of high-yielding dairy cows.Czech. J. Anim. Sci.54(6): 239-248.

Gultom, E. P., T. H. Wahyuni dan M. Tafsin. 2016. Kecernaan serat kasar dan protein kasar ransum yang mengandung pelepah daun kelapa sawit dengan perlakuan fisik, biologis, kimia dan kombinasinya pada domba. Jurnal. Peternakan Integratif. 4 (2) : 193-202.

Maynard, L.A., J. K Loosil, H. F. Hintz and Warner, R.G. , 2005. Animal Nutrition. McGraw-Hill Book Company. New York, USA.

McDonald, P., R. Edwards, J. Greenhalgh, and C. Morgan. 2002. Animal Nutrition.Longman Scientific \& Technical, New York.

Natsir, A., Harfiah, M.Z. Mide dan Rinduwati. 2014. Kinerja ternak kambing jantan lokal yang mendapat ransum komplit berbasis tongkol jagung dengan sumber protein berbeda. Laporan penelitian, LP2M Universitas Hasanuddin.Makassar.

Paramita, W. L., W. E. Susanto, dan A. B. Yulianto. 2008. Konsumsi dan kecernaan bahan kering dan bahan organik dalam haylase pakan lengkap ternak sapi peranakan Ongole. Media Kedokteran Hewan. 24: 59-62.

Rahman, M. M., R. B Abdullah, W. E. Wan Khadijah., T. Nakagawa and R. Akashi. 2013. Feed intake, digetibility and growth performance of goats offered napiergrass suplemented with molasses proctected palm karnel cake and soya waste. Asian Journal of Animal and Veterinary Advances. 8 (3) : 527-534.

Ranjhan, S.K. 1981. Animal Nutrition in Tropics.Second Revised Edition. Vikas Publishing House PVT LTD, New Delhi.

Sandri, A. 2009. Suplementasi Blok Multinutrisi Berbasis Hijauan Lapangan terhadap Kecernaan In Vivo pada Domba Jantan. Departemen Peternakan, Fakultas Pertanian, Universitas Sumatera Utara, Medan.

Siregar, S.B. 2009. Ransum Ternak Ruminansia. Penebar Swadaya. Jakarta

Tillman, A. D., H. Hartadi, S. Reksohadiprodjo, S. Prawirokusumo dan S. Lebdosoekojo. 2005. Ilmu Makanan Ternak Dasar. Gadjah Mada University Press, Yogyakarta. 
A.Antisa, A. Natsir, S. Syahrir / Bulletin Makanan Ternak, 2020-02-11: 1-13

Tillman, A. D., H. Hartadi, S. Reksohadiprojo,S. Prawirokusumo dan S. Lendosoekodjo. 1998. Ilmu Makanan Ternak Dasar. Cetakan Kedua Peternakan. Gajah Mada University Press, Yogyakarta. 